\title{
The Role of Environmental Governance in Solid Waste Management, Policy Implementation in Nairobi County
}

\author{
Florence Ogutu $^{1^{*}}$ Dr. Dennis Kimata ${ }^{1}$ Dr. Raphael Kweyu ${ }^{2}$ \\ 1.Wangari Maathai Institute for Peace and Environmental Studies, University of Nairobi, \\ P.O Box 30197 - 00100 GPO Nairobi, Kenya \\ 2.Kenyatta University, P.O Box 43844 - 00100, Nairobi, Kenya
}

The research is financed by Self-funding

\section{Abstract}

Solid waste management in Nairobi County is a growing threat to environmental health and wellbeing if the policy implementation is not governed appropriately. Dumpsites are sprouting everywhere exposing the inefficiencies in the policy implementation in Solid Waste Management. Environmental governance takes center stage in setting standards in policy implementation in terms of capacity, financial prudence and enforcement. The study was guided by this objective; to analyze the existing policy framework on solid waste management and its effectiveness in addressing SWM in Nairobi County. The study adopted descriptive research design, interrogating the stakeholders involved in the implementation of the policy frameworks in place through a good governance practices. Data was collected using semi-structured questionnaires administered to 385 respondents and 10 key informants' interviews with specialization in Solid Waste Management. The theoretical framework was based on Institutional theory and capacity building theories which expound the gaps in policy implementation. Environmental Governance in SWM dominates the development agenda and is key to sustainable waste management. This paper highlights the role of environmental governance in the context of policy implementation and the constraints.

Keywords: Solid waste management, Policy frameworks implementation, Environmental Governance.

DOI: $10.7176 / \mathrm{CER} / 11-10-06$

Publication date: November $30^{\text {th }} 2019$

\section{Introduction}

Environmental governance in Solid waste Management in Nairobi has been challenged in the implementation of policy and its enforcement (NEMA 2014). The SWM collection systems are inefficient and disposal systems have least environmental friendliness where 30 to 40 percent of all solid waste generated in urban areas is uncollected and less than half of the population being served (Otieno 2010). With the urban population in Nairobi growing at almost double the rate, higher than that of the country's general population growth rate, waste generation shall be a major challenge if environmental governance is not checked ( Ngoc \& Schnitzer, 2009; NEMA 2014).

Kenya's waste generation has been accelerating due to the rapid urbanization, the current amount (about 4 million tones/ yearly) generated is expected to double by 2030 (Njoroge et al. 2014). However, the rise in waste generation has not been accompanied by an equivalent increase in the capacity of the relevant urban authorities and financial prudence to deal with this challenge of solid waste management (Gakungu 2012; Oyake, 2017).

The sustainability agenda in Nairobi should focus on the needs of present generations being met without compromise which should be applicable too in SWM (UNEP 2018). This can be attained by providing an avenue for integrating SWM with the environment through environmental governance in policy implementation in SWM with emphasis on material and energy recovery (Marshall \& Farahbakhsh 2013, Mmereki et al. 2016).

The implementation of SWM policies in Nairobi require institutional and implementation mechanism proposed by environmental governance that are sustainable and practical (Asase et al. 2009, Haregu, et al. 2017). Consequently, in response to the consistently increasing challenge of solid waste management, several policy frameworks are formulated and enacted to address it (Murad et al. 2012).

Solid waste management and its effects is cross cutting and multi-sectoral therefore, to effectively address the challenge of solid waste management, policy integration among and within the various sectors and stakeholders is essential and critical using governance structures (Marshall \& Farahbakhsh 2013). Policy integration concerns in the management bears cross-cutting issues in policy-making that transcend the boundaries of established policy fields, and which do not correspond to the institutional responsibilities of individual departments and is impeded by poor governance structures (Persson 2004). Policy integration makes reference to management of policy responsibility within a single organization or sector where integration encompasses both horizontal sectoral integration (between different departments and/or professions in public authorities) and vertical intergovernmental integration in policy-making (between different tiers of government), or combinations of both (Persson, 2004; Tilahun et al. 2016). Conspicuously, the sector-specific and embedded solid waste management policies are coherent with the overall policy document, but they lack mechanisms of SWM implementation and environmental governance. Major gaps exist in stipulating clear policy strategies and governance mechanisms in 
SWM policy implementation in Nairobi County (Gakungu 2011; Oyake 2012; Njoroge et al.2014).

In line with the Constitution of Kenya, the National Environment Policy outlines responsibilities for the government in detail and what the government will do in relation to creating a favorable ground for protecting the environment in within SWM policy frameworks (NEP 2013). The intention of National Solid Waste Management strategy is to address a core area of the National environment policy, which aims to establish a platform for action between stakeholders to systematically improve SWM and enhance environmental governance (NEMA 2014).

Retrospectively, the integration between the Environment Policy and the Solid Waste Management Strategy is a vertical one where the policy outlines the core issues and the strategy formulated however, the role of environmental governance not fully being underscored and highlighted in Nairobi County SWM policy. Despite the presence of legislative and institutional frameworks governing solid waste management, there is so much waste as a result of indiscriminate littering and illegal dumpsites, illustrating lack of coordination and enforcement of the various laws in Nairobi County (Njoroge et al. 2014).

Environmental governance can be enhanced in the SWM institution in Nairobi County by having clear mandates on waste collection, resource recovery, recycling and disposal (AfDB 2015). The institutions are therefore in a position to introduce the concepts of clean environment by ensuring good practices, strive to conduct their activities and use of resources in a manner that develops environmental awareness and fosters responsible solid waste management (Marshall \& Farahbakhsh, 2013; Ngau 2009). Thus, waste managers need to take steps to help align the information on SWM presented to the public to ensure sustainability and enforcement through capacity building. Growing costs, shortage of funds, institutional deficiencies, indiscipline among the work force, lack of trained personnel and political pressure are making the situation worse in Nairobi County (Asnani et al. 2008; Joseph 2006).

A study by (Kasozi \& Von Blottnitz on solid waste management in Nairobi (2010) found that there were no monitoring mechanisms on the enforcement of the environmental Laws which include SWM policies that underscores the importance of environmental governance in SWM in Nairobi County. This paper seeks to illustrate the role of environmental governance in SWM policy implementation in Nairobi County.

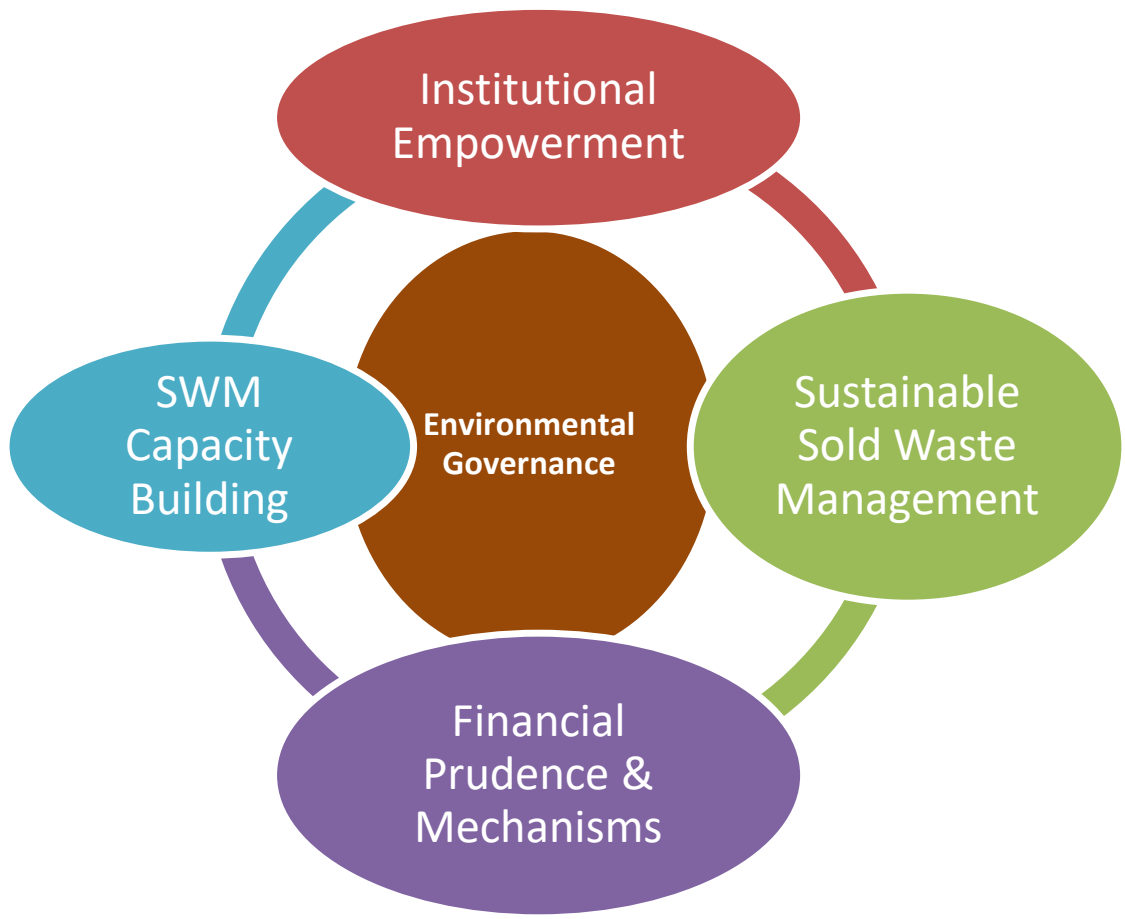

Figure 1: Conceptual Framework

The figure above shows the interrelationship between the components of environmental governance for sustainable solid waste management system.

\section{Materials and Methods}

The study approach was based on the theoretical framework of institutional analysis and capacity building theories where environmental governance is vital in the implementation of SWM policies in Nairobi County (UNEP \& ISAWA 2015). A conceptual framework (Fig. 1) was utilized to design the study where empowered SWM institutions and effective SWM environmental policies are dependent on creating a sustainable SWM through public awareness and stakeholders' participation and engagement which is grounded on environmental governance. 
Data was collected in Nairobi being the capital city of Kenya where concerned Ministries, Ministry of Environment and Natural Resources and NEMA, who formulates policies on SWM for the entire country, where policy regulators and implementers are also domiciled. Surveys were conducted using semi structured questionnaires and key informant interviews. The study adopted a mixed design approach with a target population of 385 households derived from a sampling formula that give equal representation of the samples. Data was collected by administration of questionnaires supplemented by interviews and Focus Group Discussions. Data was analyzed quantitatively using SPSS version 20 and qualitatively based on the emerging themes (Agarwal, 1991).

\section{Results}

Effectiveness in the Nairobi SWM Environmental policies

Table 1: The enforcement of environmental policies on solid waste management in Nairobi City County highlighting environmental governance

\begin{tabular}{|c|c|c|c|c|c|c|c|c|c|}
\hline Response & Male & Female & Total & Male & Female & Total & Male & Female & Total \\
\hline Agree & 9 & 0 & 9 & 60 & 12 & 72 & 38 & 11 & 49 \\
\hline Disagree & 26 & 4 & 30 & 47 & 4 & 51 & 61 & 24 & 85 \\
\hline $\begin{array}{l}\text { Strongly } \\
\text { Agree }\end{array}$ & 0 & 1 & 1 & 6 & 3 & 9 & 1 & 1 & 2 \\
\hline $\begin{array}{l}\text { Strongly } \\
\text { Disagree }\end{array}$ & 16 & 2 & 18 & 6 & 0 & 6 & 34 & 18 & 49 \\
\hline Total & 51 & 7 & 58 & 119 & 19 & 138 & 134 & 54 & 188 \\
\hline
\end{tabular}

$62 \%$ of the respondents disagreed that enforcement of environmental policies on SWM in NCC has not been carried out properly, as opposed to $36 \%$ who agreed illustrating a gap in the implementation of the set policies. Most of the respondents who disagreed that there has been effective implementation are members of the lowerclass zone - Kibra, at 35\% unlike Lavington and Embakasi. Moreover, the focus group discussions with University of Nairobi Chiromo campus students and CBOs at Kibra, key informant interviews with private service providers, hotel institutions of middle and upper categories and Resident Associations of Lavington agreed that implementation of policies is not effective indicating the gap in environmental governance.

Table 2: Environmental Impacts of Poor SWM policies implementation in Nairobi County

\begin{tabular}{llllllllll}
\hline Response & Male & Female & Total & Male & Female & Total & Male & Female & Total \\
\hline $\begin{array}{l}\text { Strongly } \\
\text { disagree }\end{array}$ & 0 & 0 & 0 & 0 & 0 & 0 & 1 & 1 & 2 \\
$\begin{array}{l}\text { Disagree } \\
\text { Agree }\end{array}$ & 1 & 0 & 1 & 1 & 0 & 1 & 6 & 3 & 9 \\
$\begin{array}{l}\text { Strongly } \\
\text { agree }\end{array}$ & 41 & 7 & 48 & 35 & 6 & 41 & 52 & 18 & 71 \\
Total & 51 & 7 & 58 & 119 & 19 & 138 & 134 & 54 & 188 \\
\hline
\end{tabular}

Majority of the respondents at 55\% agreed that the environmental conditions predisposed to proper SWM affect people's health as opposed to $42 \%$ who disagreed which illustrates the role of environmental governance in Nairobi County. This implies that the effectiveness of the policies is in enforcement and implementation mechanisms that should be consistently adhered to.

SWM policies implementation in Nairobi County affected by Institutional Capacity Table 3: The Nairobi City County as an institution has conducted SWM Public Awareness

\begin{tabular}{llllllllll}
\hline Response & Male & Female & Total & Male & Female & Total & Male & Female & Total \\
\hline No & 11 & 0 & 11 & 74 & 13 & 87 & 105 & 51 & 156 \\
Yes & 40 & 7 & 47 & 45 & 6 & 51 & 29 & 3 & 32 \\
Total & 51 & 7 & 58 & 119 & 19 & 138 & 134 & 54 & 188 \\
\hline
\end{tabular}

Majority of the respondents, at $65.9 \%$ concur that public awareness needs to be conducted more on SWM. However, the lack of SWM capacity, corruption and negligent in NCC officers creates a hindrance to public awareness unlike $34.1 \%$ who expressed satisfaction with the Nairobi City County's public awareness. 
Limitations of SWM policies implementation in Nairobi County

Table 4: The limitations of the SWM Policies implementation

\begin{tabular}{|c|c|c|c|c|c|c|c|c|c|}
\hline Response & Male & Female & Total & Male & Female & Total & Male & Female & Total \\
\hline No problem & 0 & 0 & 0 & 0 & 0 & 0 & 3 & 2 & 5 \\
\hline Problem & 5 & 0 & 5 & 30 & 7 & 37 & 32 & 17 & 49 \\
\hline $\begin{array}{l}\text { Slight } \\
\text { Problem }\end{array}$ & 0 & 0 & 0 & 6 & 1 & 7 & 3 & 1 & 4 \\
\hline $\begin{array}{l}\text { Serious } \\
\text { Problem }\end{array}$ & 46 & 7 & 53 & 83 & 11 & 94 & 96 & 34 & 130 \\
\hline Total & 51 & 7 & 58 & 119 & 19 & 138 & 134 & 54 & 188 \\
\hline
\end{tabular}

Majority of the respondents, at $72 \%$ were concerned about an overloaded waste disposal truck scattering waste on the road where it illustrates the limitations of SWM policy implementation in Nairobi County. While $28 \%$ of the respondents stated they would not be bothered with waste disposal truck littering because NCC should have policy measures in place showing the limitations in the attitudes of respondents in regard to SWM.

Table 5: The Benefits of Environmental governance in SWM Policies Implementation

\begin{tabular}{llllllllll}
\hline Response & Male & Female & Total & Male & Female & Total & Male & Female & Total \\
\hline $\begin{array}{l}\text { Strongly } \\
\text { disagree }\end{array}$ & 0 & 0 & 0 & 0 & 0 & 0 & 3 & 1 & 4 \\
$\begin{array}{l}\text { Disagree } \\
\text { Agree }\end{array}$ & 0 & 0 & 0 & 1 & 0 & 1 & 6 & 4 & 10 \\
$\begin{array}{l}\text { Strongly } \\
\text { agree }\end{array}$ & 15 & 5 & 38 & 61 & 11 & 72 & 78 & 37 & 115 \\
Total & 51 & 7 & 58 & 57 & 8 & 65 & 47 & 12 & 59 \\
\hline
\end{tabular}

$58 \%$ of the respondents concurred that waste is a resource that can be harnessed to create wealth, employment, and reduce pollution of the environment, with effective governance structures of SWM policies implementation unlike the $42 \%$ of the respondents who indicated that there was no wealth creation from waste generated. The benefits ranged from a clean environment to employment opportunities for the growing number of youth population in the city which tackles the double rate of waste generation in Nairobi County.

\section{Discussion}

The data from the results supports the respondent's views that institutions on SWM are enhanced by effective environmental governance in implementation of SWM policies in Nairobi County (Gakungu, 2012; Ngau 2009). The data illustrates the critical role of environmental governance in SWM policies with emphasis being on capacity building and financial prudence (UNEP, 2015; Marshall \& Farahbakhsh 2013; Njoroge et al. 2014)

Majority of the respondents seemed to be aware of the existence of Solid Waste Management regulations and policies but are neither empowered to enforce the policies and regulations using SWM Policy frameworks. This data, as supported by other previous authors also suggests that SWM policies when implemented and combined with strong enforcement measures through empowered institutions and stakeholders becomes sustainable and profitable (Aini et al. 2002; Joseph 2006; UNEP 2015). These SWM policy frameworks in Nairobi County when implemented strategically could strengthen the weak links between various stakeholders and enhance the public awareness on SWM as is supported by the data that shows respondents agreed there were benefits attributed to environmental governance (Aini et al. 2002). Consequently, majority of the respondents agreed that empowered institutions are vital in successful implementation of SWM policies which would enhance waste free and clean environment. The data is suggestive of the fact that once institutions/policies put in place can upscale the SWM sustainability and strengthening the financial prudence through environmental governance.

The data however elucidates optimism in empowered SWM institutions and effective SWM environmental policies application in Nairobi County which can be replicated in other counties too thereby ensuring sustainable management of solid waste in Nairobi County by highlighting the role of environmental governance (Troschinetz 2009; Gakungu, 2012).

\section{Conclusion}

The study concludes that the role of environmental governance is paramount in the sustainable SWM in Nairobi County. It explicates the intricacies between financial prudence and capacity building of SWM institutions and their critical role in solid waste management in Nairobi County. 


\section{Recommendations}

The study recommends that there is need for a clear coordination mechanism of policy making, implementation and evaluation and create synergy among the stakeholders in their implementation as well as enhancing institutional capacity (infrastructural, financial and human resources) through embedding environmental governance.

\section{References}

Agarwal, B.L. (1991). Basic Statistics, New Delhi: Wiley Eastern Limited, New Age International Ltd; $2^{\text {nd }}$ Ed. AfDB, (2015) Study on solid waste management options for Africa

Aini, M S, Razi, A F Lau, S. M \& Hashim, A. H. (2002). Practices, attitudes and motives for domestic waste recycling. International Journal of Sustainable Development and World Ecology, 9(3), 232

Allison, K \& Von Blottnitz H (2010) Solid waste management in Nairobi, a situational analysis, technical document accompanying the integrated solid waste management plan.

Asase, M, Yanful, E K Mensah, M, Stanford, J \& Amponsah, S (2009). Comparison of municipal SWMS in Canada and Ghana: A case study of the cities of London, Ontario, and Kumasi, Ghana. WM 29 (10) 277986.

Asnani, PU, Da Zhu, Zurbrugg, C, Anpolsky, S \& Shyamal, M (2008) Improving Municipal solid waste management in India: A Source book for Policy Makers and Practitioners, World Bank Institute Development Studies.

Gakungu, N K Njoroge B \& Kimani, M (2012) Solid waste management in Kenya: A case study of public technical training institutions ICASTOR Journal of Engineering 2012; 5(3):127-138

Retrieved from https://profiles.uonbi.ac.ke/mary/publications/solid-waste-management-kenya-Case-study-publictechnical-training-institutions.

Haregu, TN, Ziraba, AK, Aboderin, I (2017) An assessment of the Evolution of Kenya's solid Waste Management Policies and their Implementation in Nairobi and Mombasa: analysis of Policies and practices. Environment and Urbanization 29:515-532

Joseph, K. (2006). Electronic waste management in India: Issues and strategies, paper presented at the Eleventh International Waste Management and Landfill Symposium, Cagliari, 1-5 October.

Marshall, RE,.Farahbakhsh, K (2013). Systems approaches to integrated solid waste management in developing countries. Waste Management, 33(4), 988- 1003.

Ministry of Environment WaNR (2013). National Environment Policy Nairobi, Kenya: Ministry of Environment, Water and Natural Resources; 2013

Mmereki, D, Baldwin, A \& Li, B (2016) A comparative analysis of solid waste management in developed, developing and lesser-developed countries. Environmental Technology Reviews 5: 120-141.

Mugenda, A. (2008). Social Science Research: Theory and Principles. Nairobi: Applied Research and Training Services. Acts Press, Nairobi. Retrieved from http://www.sciepub.com/reference/141181

Murad, W M, Hasan, M M \& Shoeb-Ur-Rahman, M (2012). Relationship between personality traits of the urban poor concerning solid waste management and household income and education. Interdisciplinary Description of Complex Systems, 10(2), 174-192.

National Environmental Management Authority (2010). Kenya State of Environment Outlook 2010: Supporting the Delivery of Vision 2030. Nairobi

National Environmental Management Authority (2014) The National Solid Waste Management Strategy, NEMA Nairobi City County (2015). Nairobi City County Solid Waste Act 2015.

Ngau \& Kahiu. (2009). ISWM Secondary Data Report on Solid Waste Inventory in Nairobi: Report of the National Technical Taskforce (NTT) on Preparation of An Integrated Solid Waste management Plan for Nairobi.

Ngoc, N U \& Schnitzer, H. (2009). Sustainable Solutions for Solid Waste Management in South East Asian Countries. WM 29 (6) 1982-95.

Njoroge, BNK, Kimani MW\& Ndunge D. (2014). Review of Municipal Solid Waste Management: A Case Study of Nairobi, Kenya. Research Inventory: International Journal of Engineering and Science. 4(2). Retrieved from https://profiles.uonbi.ac.ke/mkimani65/publications/review-municipal-solid-Waste-management-casestudy-nairobi-Kenya.

Otieno, T. (2010). Storm clouds of our solid waste may blow us away if we don't act now; daily Nation Newspaper, 25 October 2010.

Oyake, O (2012) Managing plastics waste in Urban Kenya, Niche Innovations in production and Recycling. Doctoral dissertation, Wageningen University, Netherlands

Oyake, O (2017) Awareness on Environmentally Sound Waste Management by Communities and Municipalities in Kenya, UNDP. Available at: file: users/veraweghmann/ Desktop/ Awareness\%environmentally\%Ssound\%soild\%20waste\%20management.Pdf

Persson, Å (2004). Environmental Policy Integration: An Introduction. In: Sustainability PPIf, editor. Stockholm: 
Stockholm Environment Institute 2004.

Tilahun, N H, Abdhalah K Z \& Mberu, B. (2016). Integration of Solid Waste Management Policies in Kenya: Analysis of coherence gaps and overlaps, African Population and Health Research Center, Nairobi, Kenya.

Troschinetz, A M \& Mihelcic, J R. (2009). Sustainable recycling of municipal solid waste in Developing countries. Waste Management, 29(2), 915-923.

UNEP and ISAWA (2015) Global Waste Management Outlook. In ISAWA World Congress 2015 (pp47).https//doi.org/10.1177/0734242X15616055

UNEP (2015) (United Nations Environment Programme). (2015). Retrieved February 10, 2015. http://www.unep.org/gpwm/FocalAreas/IntegratedSolidWasteManagement/tabid/56457/Default.aspx

UNEP. (2015). Global Waste Management Outlook (GWMO) Waste - Still A Global Challenge In The 21st Century the Gwmo at a glance, 1-2.

United Nations Environment Programme (UNEP) (2018) Africa Waste Management Outlook. United Nations Environment Programme, Nairobi, Kenya. Available at: https://www.csir.co.za/documents/africa-wmoreportpdf (accessed 10 July 2018) 